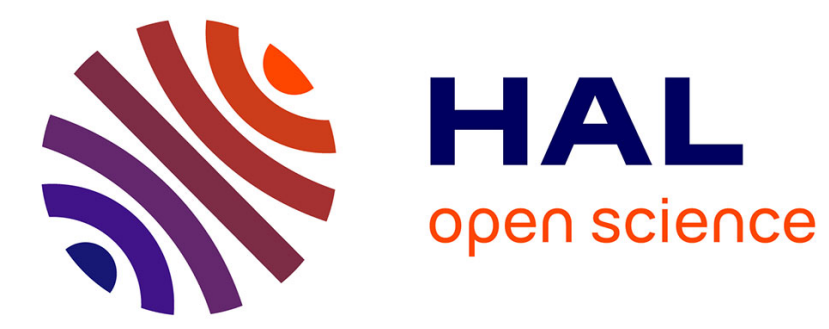

\title{
Towards a New Culture of Athletic Success?
}

Stéphane Couckuyt

\section{To cite this version:}

Stéphane Couckuyt. Towards a New Culture of Athletic Success?. International Sport Coaching Journal, 2017, 4 (1), pp.115-116. 10.1123/iscj.2016-0082 . hal-01585140

\section{HAL Id: hal-01585140 https://hal-insep.archives-ouvertes.fr/hal-01585140}

Submitted on 11 Sep 2017

HAL is a multi-disciplinary open access archive for the deposit and dissemination of scientific research documents, whether they are published or not. The documents may come from teaching and research institutions in France or abroad, or from public or private research centers.
L'archive ouverte pluridisciplinaire HAL, est destinée au dépôt et à la diffusion de documents scientifiques de niveau recherche, publiés ou non, émanant des établissements d'enseignement et de recherche français ou étrangers, des laboratoires publics ou privés. 


\section{Towards a New Culture of Athletic Success?}

Book « Sport - Pour une culture de la gagne », Jacques Piasenta - 2015 - Amphora. ISBN 978-2851809100. Price 19.50 euros (approximately 22.10 dollars)

Reviewed by Stéphane Couckuyt, PhD student, Paris-Est University in Créteil, Ile de France, France.

In his fifth book published in 2015 (after Piasenta, 1988, 2001, 2006, 2011), coach Jacques Piasenta details his conceptualization of how to achieve success for both recreational and high performance sport contexts. Piasenta argues for an 'athlete oriented' instead of 'performance oriented' approach and considers the performance oriented viewpoint as "dehumanizing" (p. 8). Piasenta supports athletes striving for improved performances for internal personal reasons instead of external social factors. An approach that is congruent with typical definitions of intrinsic and extrinsic motivation. The vision offered is the marathon runner happy to have finished the race regardless of time or place in the field.

Piasenta uses his experiences from over 40 years as a track and field coach specializing in sprints and hurdles. While Piasenta certainly coaches countless non-famous athletes, some of the more decorated athletes he coached were: Michèle Chardonnet, bronze in the $100 \mathrm{~m}$ hurdles at the 1984 Olympic Games; Stéphane Caristan, gold in the $110 \mathrm{~m}$ hurdles at the 1986 European championships; Marie-José Pérec, gold in the $400 \mathrm{~m}$ at the 1991 World championships and gold in the 1992 Olympic Games; and Christine Arron, gold in the $100 \mathrm{~m}$ at the 1998 European championships and multiple international medals between 1997-1999 in the 4 x 100m relay.

The book is divided in two main parts. The first part includes 40 'key ideas' with 10 each for the athlete, the coach, the coach and athlete, and training methodology. The second portion focuses specifically on high performance sport and describes Piasenta's 8 'pillars' for winning at the highest level. To Piasenta's credit, this book is written without overly focusing on the track and field context in favor of more fundamental principles. This approach allows readers unfamiliar with track and field to identify with Piasenta's advice and ideas and while reflecting on their own practices. The text in the book is conventionally black but striking ideas and numerous illustrations punctuate this book with many quotations in orange text. For example "This is not the athlete who follows the program, this is the program that follows the athlete" (Renato Canova, p. 109) and from other fields (e.g., philosophy, biology, automobile motor engineering, space exploration, epistemology), leaving a book rich in content from well beyond track and field.

Essentially, this book is a plea by an exceptionally successful coach for a re-focusing of the sport culture that should include three fundamental dimensions leading to success:

Move away from a 'performance' perspective to one featuring self-control. Piasenta argues that the focus on self-control, (i.e., personal improvement) is better for the athlete leading to both increased performance level and experiencing greater happiness.

Build and teach critical mental and physical tools that will allow the athlete to adapt to a variety of situations within sport and in life in general, to stay balanced.

Adopting a view of life where material items are devalued in comparison to striving for personal improvement and the quality of one's life should be judged by personal and professional accomplishments and not measured in years.

With such a large total of 40 main ideas, some are relatively common, but others are more novel: (a) 'determine what to do and especially what not to do', (b) 'no brain no gain'-it is important to explain the meaning of each training session in order to enhance the athletes' capacity to think and adopt a strategic vision, (c) 'cultivate adaptability and rusticity' - train in a large variety of situations, (d) 'the coach must understand to observe and not observe to understand'-- the understanding of what a coach sees is far more important than simply watching and gathering data, and (e) 'coach to the second degree'deal with causes, not with effects. Piasenta specifically addressed in influx of technology in sport pointing out that 'effectiveness is more important than appearance', so the focus should be on having a specific purpose for employing the technology and keep it simple. It is not whether the coach is using a tablet computer or a paper

Stéphane Couckuyt is a $\mathrm{PhD}$ student in education with a major of sport psychology at Paris-Est University in Créteil, Ile de France, France. He is a teacher in sport science at the Paris-Est University in Créteil, Ile de France, France. He has over 10 years of professional experience in coaching and athletic administrative positions in different clubs in Karate and Boxe. He is a Certified Strength and Conditioning Specialist through the University of Bordeaux and he received a bachelor degree in management from the University of Lyon. 
notebook, it is how, and for what purpose the coach uses the tools available. Piasenta highlights the fact that in a technology world and with information overload, it's the skills of the coach and the athletes who make difference. He also identifies a critical distinction between technique and performance for athletes. Piasenta wants readers to understand that even in a record-setting performance an athlete's technique could be average. Piasenta uses this distinction to explain his belief in splitting training sessions with one session focusing on the athlete's overall development and the second focusing exclusively on technique.

Balance in an athlete's life is critical in Piasenta's eyes, even at the most elite levels of sport. Piasenta insists athletes must maintain balance between their athletic and non-athletic identities. Piasenta argues there are so many competing parts of an athlete's life (e.g., between being an athlete and all parts not related to being an athlete; media responsibilities versus training responsibilities; focusing on self-improvement versus team improvement; between time spent training and spent on other hobbies or occupations) that forgetting any one of them will lead to reduced performance and less happiness. For him, to become and stay a champion, it's a matter of balance and Piasenta thinks that the coach has an important role to help the athlete maintain balance. Among the numerous athletes he trains, Piasenta notes that the best are sometimes not balanced between the sport and the rest of their life. But those athletes that maintain a high level of success have found a way to lead a balanced life. Piasenta acknowledges an athlete can become a champion and lack balance but that athlete will not remain a champion for long. The post-career transition is especially important to consider with respect to balance because the competitions will end at some point and an athlete that has not been living a balanced life will struggle in athletic retirement.

Finally, given the rarity of coaching resources in French, this book fills an obvious void. The book is not written referencing scientific data but does leave the reader with a feeling of gaining access to the thoughts of a highly successful coach sharing his experience and lessons from decades coaching. With Piasenta including contexts outside of track and field, it allows the reader's mind to wander and translate Piasenta's ideas into the reader's own context increasing the potential reach of this book. For each of Piasenta's key ideas, the reader is presented to reflect on what Piasenta suggests compared with what the reader believes about the key idea.

\section{Acknowledgments}

Thank you to Alexandre Guyon Des Diguères for his English reviewing.

\section{References}

Piasenta, J. (1988). L'éducation Athlétique. Paris: INSEP Edition.

Piasenta, J. (2001). Apprendre à observer. Paris: INSEP Edition.

Piasenta, J. (2006). Carnet de piste: une aventure humaine et sportive. La Plaine-Saint-Denis (Seine-Saint-Denis): Night \& day library.

Piasenta, J. (2011). Motricité sportive développement des capacités et habiletés. Paris: Amphora. 